\title{
Study-abroad, Language Proficiency, and Learner Beliefs about Language Learning
}

\section{Koichi Tanaka}

\author{
Auckland Institute of Studies \\ Rod Ellis \\ University of Auckland
}

This article reports an empirical study of a 15-week study-abroad program for Japanese university students, examining changes in the students' beliefs about language learning (measured by means of a questionnaire) and in their English proficiency (measured by means of the TOEFL). The results showed statistically significant changes in the students' beliefs relating to analytic language learning, experiential language learning and self-efficacy/confidence during the study-abroad period. Statistically significant gains in proficiency are also reported. However, Pearson product moment correlations between the students' responses to the Belief Questionnaire and their TOEFL scores both before and after the study-abroad period were weak and generally statistically non-significant. The results are discussed in relation to study-abroad programs and also to the role of learner beliefs in second language learning.

本稿は、15週間の海外留学プログラムに参加した日本人大学生の言語学習に関する確信 （beliefs）と英語能力の変化を、質問紙とTOEFLを用いて測定した調査の報告である。分 析の結果、留学経験後、分析的言語学習、経験的言語学習、そして自己能力・自信に関す る学生達の確信に、統計的に有意な変化が見られた。また英語能力に関しても、統計的に 有意な変化が見られた。しかし、質問紙への回答に表れた学生達の言語学習に関する確信 とTOEFLスコアの相関は、留学前も留学後も弱く、統計的に有意なものではなかった。 こうした結果を、海外留学プログラムや第二言語習得における学習者の確信の役割と関連 付けて論じる。

$\mathrm{L}$

earner beliefs, along with factors such as language aptitude and motivation, are considered key elements contributing to individual learner differences in second language (L2) learning. Learner beliefs influence learners' behaviours, in particular, choice of learning

JALT Journal, Vol. 25, No. 1, May, 2003 
strategies, and their affective states such as confidence and anxiety, and thereby affect both linguistic outcomes (i.e., changes in competence, knowledge, and skills in some aspect of the target language) and nonlinguistic outcomes (i.e., changes in reactions to the target language, the situation, and/or factors associated with the target language) (Ellis, 1994; Gardner \& MacIntyre, 1992, 1993). A social psychological perspective on beliefs also indicates that an individual's personal experience has a great influence on his or her beliefs (Corsini, 1994; Fishbein \& Ajzen, 1975). Thus, experience of learning a language in a different environment (e.g., a new teacher, new teaching material, a new setting) may lead to learners modifying their existing beliefs or forming new ones. In other words, the relationship between beliefs, behaviours, and learning outcomes is an interactive and dynamic one.

A common belief among language learners and educators is that the best way to learn a language is to live in a country where the language is used. This belief is reflected in the large number of Japanese that go to English-speaking countries to study English or other academic subjects every year. Also, in recent years, many Japanese universities and twoyear colleges have established study-abroad programs that "combine a period of residence in another country...with classroom-based language and/or content area study" (Freed, 1995, p. 5) in order to improve not only students' language ability and academic knowledge but also their cultural awareness.

Studies of learner beliefs about language learning have focused mainly on what beliefs learners hold and how learners' backgrounds (e.g., nationality and previous language learning experiences) affect their beliefs. Few researchers have examined how learner beliefs change as a result of learning experience over a period of time nor have they looked at the relationship between beliefs and language proficiency. Furthermore, there has been little research into the effects of studyabroad programs on Japanese students' learning of English. The study reported here constitutes an initial attempt to address these issues.

\section{Learners' Beliefs About Language Learning}

Although quite a few studies of learners' beliefs about language learning have been conducted in a number of different settings since the two pioneering studies in the 1980s (Horwitz, 1985; Wenden, 1986), there is still no general consensus about how to categorize learner beliefs. The number and content of categories have varied from study to study. Following an extensive review of the research, Tanaka (1999) 
identified two broad dimensions of learner beliefs: (a) beliefs about self as a language learner (e.g., self-efficacy, confidence, aptitude, motivation) and (b) beliefs about approaches to language learning. The latter could be subdivided into beliefs about analytic and experiential learning.

Previous studies have shown that learner beliefs vary according to a number of factors such as age, cultural (or ethnic) background, learning environment, stage of learning, and target language (Horwitz, 1999; Rifkin, 2000). In other words, learner beliefs are situation-specific. Some studies (e.g., Matsuura, Chiba, \& Hilderbrandt, 2001; Sakui \& Gaies, 1999; Tanaka, 2000) reported that Japanese university EFL students thought that English classes should be enjoyable but that, in general, they did not find them so. The students also believed that listening to the radio or watching TV in English was important for learning English. However, many students also reported preferring traditional teaching methods involving a teacher-centred approach and a focus on accuracy. Also, they indicated that speaking English made them nervous, and they held negative beliefs about how successful they could be.

There have been very few studies of the relationship between learner beliefs and learning outcomes to date. In one study, Park (1995) investigated 332 Korean university EFL students' beliefs about language learning, their language learning strategies, and the relationships among their beliefs, strategy use, and L2 proficiency. Park found three variables predicted students' TOEFL scores to some extent. One was a belief variable (i.e., beliefs about self-efficacy and social interaction) and two were strategy variables (i.e., independent/interactive strategies and metacognitive strategies). Those learners who reported having confidence in learning English and the intention of speaking to others in English tended to use English actively, especially outside the classroom, and to monitor their progress in English carefully. These behaviours were also related to improvement in L2 proficiency.

Mori (1999) investigated the beliefs of 187 university students of various proficiency levels enrolled in a Japanese course in the U.S. She examined the relationship between epistemological beliefs (i.e., beliefs about learning in general) and beliefs about language learning and also the relationship between beliefs and L2 achievement. She found that strong beliefs in innate ability (i.e., the ability to learn is inherited and cannot be improved by effort) and in avoidance of ambiguity (i.e., the need for a single, clear-cut answer) were associated with lower achievement. Learners who believed that L2 learning was easy 
manifested higher levels of achievement. In addition, this study showed that there were belief differences between novices and advanced learners. Advanced learners were less likely than novice learners to believe in simple, unambiguous knowledge or the existence of absolute, single answers. This study also revealed that epistemological beliefs and beliefs about language learning were for the most part unrelated. In other words, learner beliefs about language learning seemed to be task- and domain-specific.

Kern (1995) reported changes in the beliefs of 180 students studying first-year French at a university in the U.S. over the course of one semester (15 weeks). He administered the "Beliefs About Language Learning Inventory" (BALLI) (Horwitz 1985, 1988) during the first and last week of the semester. Kern reported that 35\% to 59\% of the responses changed over the 15-week period. A significant change was observed in the response to the statement "If you are allowed to make mistakes in the beginning, it will be hard to get rid of them later on," with $37 \%$ of the students reporting greater agreement and 15\% lesser agreement in the last week. This suggests that many students had become increasingly conscious of their mistakes and were having difficulty in avoiding them. The learners also changed their responses to the statement "Learning a foreign language is mostly a matter of learning a lot of grammar rules," with 32\% showing greater agreement and 20\% lesser agreement.

\section{Study-abroad and L2 Learning}

Since Carroll's (1967) original study of the relationship between the language proficiency of 2,782 American students majoring in French, German, Italian, and Russian and their study-abroad experiences, a number of studies have examined the effect of the study-abroad experience on language learning. A general assumption is that natural settings involving informal learning through out-of-class contact with the L2 leads to higher levels of proficiency than educational settings where instruction is provided. Thus, study-abroad is seen as valuable because it provides opportunities for informal learning. However, Ellis (1994) pointed out that some studies have challenged this assumption in two ways. First, they showed that natural settings did not necessarily bring about higher proficiency; educational settings often resulted in higher proficiency, especially higher grammatical competence. Second, even in natural settings, the amount of contact with the target language had less influence on language learning than the type of the contact, 
which differed depending on learners' initial levels of proficiency. For example, Freed (1990), in a study of the effects of contact on the L2 proficiency of 40 undergraduate American students in a six-week studyabroad program in France, reported that, for the lower-level students, increased interactive contact (e.g., speaking with native speakers) led to clear gains in the test scores on grammar and reading while it did not have the same effect for advanced-level students. In contrast, non-interactive contact (e.g., reading newspapers, watching television) benefited the advanced but not the lower-level students.

Freed (1993, 1995, 1998) and Coleman (1997) provided surveys of previous studies of the effects of study-abroad programs on L2 learning. Their main findings were as follows:

1. Accuracy and complexity, measured in terms of frequency of mistakes, sentence length or syntactic complexity in oral production, did not change in any noticeable way.

2. Gains in fluency, in terms of the speaking rate (syllables per minute) or phonation/time ratio (percentage of total time spent speaking), were strong.

3. Overall oral proficiency scores, measured by the ACTFL Oral Proficiency Interview (OPI), were higher in learners in study-abroad programs than in learners who did not participate.

4. Gains in overall oral proficiency scores were stronger than gains in test scores on grammar, listening, and reading.

5. Vocabulary gains, measured by vocabulary tests, were stronger than those of comparable students who did not participate in a study-abroad program.

6. The higher the students' initial level of proficiency, the lower the gains in proficiency as a result of studying abroad.

Thus, on the whole, an increase in natural exposure to the L2 through a study-abroad experience seems to contribute more to fluency and naturalness of speech (i.e., higher speech rate and fewer disfluent, silent pauses) than to accuracy and complexity of speech. Compared with gains in fluency and naturalness of speech, the improvement in grammar, listening, and reading is relatively low. However, Freed and Coleman noted that there is considerable individual variation in gains by students in the same study-abroad program. 


\section{Research Questions}

Drawing on the results of the research to date, the following research questions were formulated:

1. What changes in the learners' English language proficiency occurred during the study-abroad program?

2. What changes in the learners' beliefs about language learning occurred during the study-abroad program?

3. What relationship is there between the learners' English language proficiency and their beliefs about language learning?

4. What relationship is there between changes in learners' beliefs about language learning and changes in their English language proficiency?

\section{Method}

Design

The relationship between two variables, learners' beliefs about language learning and English proficiency, was examined in a sample of Japanese university students at two different times, 15 weeks apart. Changes in beliefs and in proficiency from Time 1 (prior to studying abroad) to Time 2 (after studying abroad) were examined. In addition, the relationship between changing beliefs and developing proficiency was studied.

\section{Participants}

The 166 participants were studying at a university in Japan. They were between 19 and 20 years old. The students had studied English for seven years on average (including 6 years at junior and senior high school). The students had been enrolled at the university for one year and were all taking English as their major. The majority of the students had never been overseas before the study-abroad program, although some students had spent up to 8 weeks overseas on holidays.

\section{The Study-abroad Program}

The 15-week study-abroad program, which took place at a private university in the northeastern part of the U.S., was organized around 
three hours of classes in the morning and various social and community activities in the afternoons. The required subjects were Speaking and Listening, Writing, Current Issues in American Society, and American Culture. Electives in Literature, Arts, Social Sciences, and Communication Studies were also offered. All the classes were taught by native speakers with postgraduate qualifications. The students also undertook a number of field trips, including a two-day trip to New York City. They stayed together on campus in dormitories but had opportunities to communicate with native speakers on shopping expeditions and with native speaking Resident Assistants who shared dormitories with the students and who took them on an outing once a week. In addition, some students participated in a volunteer program that involved two or three visits to a local nursing home, an elementary school or a museum.

\section{Instruments}

The learners' beliefs about language learning were measured by means of questionnaire consisting of 27 statements, to which the participants responded on a 5-point Likert scale ranging from strongly agree to strongly disagree (see Appendix). The content of the questionnaire was arrived at by analysing previous learner belief questionnaires (Horwitz, 1988, 1999; Rifkin, 2000; Wenden, 1986; Yang, 1992). Following Tanaka (1999), three dimensions of beliefs were identified: (a) beliefs about self (i.e., self-efficacy, confidence, aptitude, motivation), (b) beliefs about analytic learning and (c) beliefs about experiential learning. Based on this analysis, a set of 36 statements in English were prepared to examine these dimensions and then translated into Japanese. The questionnaire was then piloted on a sample of 145 learners of English, consisting of Japanese university students in Japan (who completed the Japanese version) and a mixed group of Asian students in New Zealand (who completed the English version). To determine the construct validity of the questionnaire an exploratory factor analysis of the responses was performed. This revealed three main factors (Analytic Learning, Experiential Learning, and Self-Efficacy and Confidence), which corresponded closely to Tanaka's three dimensions. However, the factor analysis also revealed that a number of the statements in the questionnaire loaded very weakly on the three factors. Therefore, to improve the questionnaire, these statements were removed and five new statements reflecting the three dimensions of 
beliefs were devised. The revised questionnaire, in both the English and Japanese versions, consisted of 27 statements (22 statements from the original questionnaire plus five new ones). The statements in the English version of the Learner Belief Questionnaire can be found in the Appendix.

In order to measure overall English proficiency, a paper-based version of the Test of English as a Foreign Language (TOEFL) was administered. It consists of three sections. Section 1 (Listening) tests understanding of short conversations and talks. Section 2 (Grammar and Written Expression) tests students' ability to recognize correct grammar. Section 3 (Reading) consists of a test of reading comprehension and includes questions about the meanings of specific lexical items and phrases.

\section{Data Collection Procedures}

Table 1 shows the schedule for the administration of the Learner Belief Questionnaire and the TOEFL. The Learner Belief Questionnaire was administered approximately three weeks before the students left for the study-abroad program and three days before they returned. Thus the first administration was carried out in Japan and the second in the U.S. In both cases, the students completed the Japanese version of the questionnaire.

It should be noted that the first TOEFL was administered some three months before the students began the study-abroad program. The second TOEFL took place 10 days before the end of the study-abroad program.

Table 1: Schedule of the Study

\begin{tabular}{ll}
\hline Instrument & Time Administered \\
\hline TOEFL 1 & 3 months before study abroad \\
Learner Belief Questionnaire 1 & 3 weeks before study abroad \\
TOEFL 2 & 13.5 weeks after start of study \\
& abroad \\
Learner Belief Questionnaire 2 & 15 weeks after start of study \\
& abroad (just prior to return) \\
\hline
\end{tabular}




\section{Data Analysis}

To establish the construct validity of the questionnaire, responses from the two administrations of the Learner Belief Questionnaire were submitted to separate Factor Analyses (SPSS; Excel Statistics 2000). In this way, it was possible to establish whether the same three factors that emerged in previous administrations (see the account of the development of the questionnaire above) were found. To examine the internal reliability of the questionnaire, Cronbach's alpha was calculated on the items relating to each of the three factors. To examine differences between the participants' TOEFL scores and their responses to the Learner Belief Questionnaire at Times 1 and 2, $t$ test scores were calculated. Independent $t$ tests followed by Bonferroni adjustments (to protect against Type 1 errors) were used to determine the significance of the differences between the participants' TOEFL scores for each section (Listening, Grammar, Reading and for Total scores), between the participants' scores for each of the three beliefs factors (Analytic Learning, Experiential Learning, and Self-Efficacy and Confidence) at Times 1 and 2 , and between their mean scores on the 27 beliefs statements at Times 1 and 2. Factor scores were arrived at by totalling an individual's scores for each statement that loaded at .40 or higher on a factor and then dividing by the number of statements, thus producing a mean score for each subject on each factor.

Pearson correlation coefficients were computed between learner beliefs and TOEFL scores at both Times 1 and 2. In addition, the changes in beliefs (i.e., the belief score on each statement for Time 2 was subtracted from the same belief score at Time 1) were correlated with gains in proficiency scores between Times 1 and 2 (i.e., by subtracting Time 1 TOEFL scores from the Time 2 scores).

An alpha level of .05 was set for all statistical tests.

\section{Results}

We will first report the results of a factor analysis of the students' responses to the Learner Belief Questionnaire at Times 1 and 2. The purpose of this analysis was to demonstrate the construct validity of the questionnaire for the sample of learners under investigation. Thus, the number of factors was set at three, corresponding to the three dimensions of beliefs. The results are shown in Tables 2 and 3. As in the previous pilot studies, three factors emerged. A close inspection of the statements loading on each factor revealed that the factors were identical to those of the pilot studies, (a) Analytic Learning, (b) Experiential 
Learning, and (c) Self-Efficacy and Confidence. Tables 2 and 3 also indicate which statements had a loading of .40 or higher on each factor in the two factor analyses. In both analyses the cumulative percentage of variance accounted for by the three factors was relatively low $(22.39 \%$ at Time 1 and 30.02\% at Time 2).

\section{Table 2: Factor Analysis of Learner Beliefs (Time 1: Before Studying Abroad)}

\begin{tabular}{|c|c|c|c|c|}
\hline tem \# & Questionnaire Items & F1 & F2 & F3 \\
\hline & \multicolumn{4}{|l|}{ Factor 1: Analytic Learning $(\alpha=.69)$} \\
\hline 20 & $\begin{array}{l}\text { I should be able to understand everything the } \\
\text { teacher says. }\end{array}$ & .635 & & \\
\hline 8 & $\begin{array}{l}\text { I should be able to understand everything I read in } \\
\text { English. }\end{array}$ & 618 & & \\
\hline 4 & $\begin{array}{l}\text { I can learn well by writing down everything in my } \\
\text { notebook. }\end{array}$ & 600 & & \\
\hline 13 & I can learn well by following a textbook. & .535 & & \\
\hline 5 & $\begin{array}{l}\text { In order to speak English well, it is important for me } \\
\text { to learn grammar. }\end{array}$ & .414 & & \\
\hline 18 & $\begin{array}{l}\text { I can learn well in a class where the teacher } \\
\text { maintains good discipline. }\end{array}$ & .405 & & \\
\hline \multirow[t]{2}{*}{27} & I would like my teacher to correct all my mistakes. & .403 & & \\
\hline & Factor 2: Experiential Learning $(\alpha=.29)$ & & & \\
\hline 22 & $\begin{array}{l}\text { I can learn well by reading English magazines or } \\
\text { newspapers. }\end{array}$ & & .602 & \\
\hline 1 & I can learn well by speaking with others in English. & & .539 & \\
\hline 10 & $\begin{array}{l}\text { I can learn well by listening to radio or watching TV } \\
\text { in English. }\end{array}$ & & .529 & \\
\hline 14 & I should not be forced to speak in the English class. & & -.469 & \\
\hline 19 & I can learn well by using English outside class. & & .425 & \\
\hline 12 & $\begin{array}{l}\text { I can learn well by living in an English-speaking } \\
\text { country (e.g., the United States). }\end{array}$ & & .417 & \\
\hline \multirow[t]{2}{*}{24} & I can learn well if I try to think in English & & .403 & \\
\hline & Factor 3: Self-Efficacy and Confidence $(\alpha=.67)$ & & & \\
\hline 26 & $\begin{array}{l}\text { It is possible for me not to get nervous when } \\
\text { speaking English. }\end{array}$ & & & .7 \\
\hline 6 & $\begin{array}{l}\text { It doesn't matter if I make mistakes when speaking } \\
\text { with others in English. }\end{array}$ & & & .509 \\
\hline \multirow[t]{4}{*}{16} & I am satisfied with my progress in English so far. & & & .403 \\
\hline & Eigenvalue & 2.56 & 2.15 & 1.34 \\
\hline & Percentage of Variance & 9.46 & 7.96 & 4.97 \\
\hline & Cumulative Percentage & 9.46 & 17.42 & 22.39 \\
\hline
\end{tabular}


Table 3: Factor Analysis of Learner Beliefs (Time 2: After Studying Abroad)

\begin{tabular}{|c|c|c|c|c|}
\hline Item \# & Questionnaire Items & F1 & $\mathrm{F} 2$ & F3 \\
\hline & Factor 1: Analytic Learning $(\alpha=80)$ & & & \\
\hline$\overline{13}$ & I can learn well by following a textbook. & .608 & & \\
\hline 4 & $\begin{array}{l}\text { I can learn well by writing down everything in my } \\
\text { notebook. }\end{array}$ & .598 & & \\
\hline 5 & $\begin{array}{l}\text { In order to speak English well, it is important for me to } \\
\text { learn grammar. }\end{array}$ & .590 & & \\
\hline 8 & $\begin{array}{l}\text { I should be able to understand everything I read in } \\
\text { English. }\end{array}$ & .589 & & \\
\hline 7 & $\begin{array}{l}\text { In order to learn well, it is important for me to review what } \\
\text { I have been taught in the English class. }\end{array}$ & .532 & & \\
\hline 20 & $\begin{array}{l}\text { I should be able to understand everything the teacher } \\
\text { says. }\end{array}$ & .526 & & \\
\hline 11 & Memorisation is a good way for me to learn English. & .479 & & \\
\hline 18 & $\begin{array}{l}\text { I can learn well in a class where the teacher maintains } \\
\text { good discipline. }\end{array}$ & .462 & & \\
\hline 2 & $\begin{array}{l}\text { If I am permitted to make mistakes in English, it will be } \\
\text { difficult for me to speak correctly later on. }\end{array}$ & .440 & & \\
\hline 17 & $\begin{array}{l}\text { Iwould like my English teacher to explain important things } \\
\text { in my first language so I can understand evervthing }\end{array}$ & .434 & & \\
\hline 27 & I would like my teacher to correct all my mistakes. & .415 & & \\
\hline \multirow[t]{2}{*}{25} & $\begin{array}{l}\text { In order to speak English well, it is important for me to } \\
\text { learn vocabulary. }\end{array}$ & .410 & & \\
\hline & Factor 2: Experiential Learning $(\alpha=.79)$ & & & \\
\hline$\overline{10}$ & $\begin{array}{l}\text { I can learn well by listening to radio or watching TV in } \\
\text { English. }\end{array}$ & & .719 & \\
\hline 19 & I can learn well by using English outside class. & & .707 & \\
\hline 24 & I can learn well if I try to think in English. & & .624 & \\
\hline 1 & I can learn well by speaking with others in English. & & .607 & \\
\hline 15 & I can learn English well if I am studying just for pleasure. & & .575 & \\
\hline 22 & $\begin{array}{l}\text { I can learn well by reading English magazines or } \\
\text { newspapers. }\end{array}$ & & .511 & \\
\hline \multirow[t]{2}{*}{21} & It's okay to guess if I do not know a word in English. & & .478 & \\
\hline & Factor 3: Self-Efficacy and Confidence $(\alpha=.56)$ & & & \\
\hline$\overline{26}$ & $\begin{array}{l}\text { It is possible for me not to get nervous when speaking } \\
\text { English. }\end{array}$ & & & .610 \\
\hline 16 & I am satisfied with my progress in English so far. & & & .497 \\
\hline \multirow[t]{4}{*}{6} & $\begin{array}{l}\text { It doesn't matter if I make mistakes when speaking } \\
\text { with others in English. }\end{array}$ & & & .416 \\
\hline & Eigenvalue & 3.47 & 3.23 & 1.40 \\
\hline & Percentage of Variance & 12.84 & 11.98 & 5.20 \\
\hline & Cumulative Percentage & 12.84 & 24.82 & 30.02 \\
\hline
\end{tabular}


The reliability of the questionnaire was then examined using Cronbach's alpha. At Time 1, the alpha for Factor 1 (Analytic Learning) was $\alpha=.69$, for Factor 2 (Experiential Learning) $\alpha=.29^{1}$ and for Factor 3 (Self-Efficacy and Confidence) $\alpha=.67$. At Time 2 , the alpha for Factor 1 (Analytic Learning) was $\alpha=.80$, for Factor 2 (Experiential Learning) $\alpha=$ .79 and for Factor 3 (Self-Efficacy and Confidence Beliefs) $\alpha=.56$. The reliability of the questionnaire is discussed below.

Table 4 shows the results for the administrations of the TOEFL prior to the study-abroad period and upon return to Japan. The mean total TOEFL score for the 166 students improved 18.55 points. The difference between Time 1 and Time 2 scores was statistically significant, but reflected an improvement of only $4.35 \%$. The largest gain in proficiency was seen in the grammar section of the TOEFL (5.88\%) and the smallest in listening (2.65\%).

Table 4: TOEFL Scores Before and After Studying Abroad

\begin{tabular}{|c|c|c|c|c|c|c|}
\hline & $\begin{array}{l}\text { Time } 1 \\
M(S D)\end{array}$ & $\begin{array}{l}\text { Time } 2 \\
M(S D)\end{array}$ & $M$ Diff. & (\%) & $t$ & $p$ \\
\hline Listening & $43.48 \quad(3.66)$ & $44.63 \quad(4.03)$ & 1.15 & $(265)$ & -351 & $* *$ \\
\hline Grammar & $42.16 \quad(5.74)$ & $(3.77)$ & 2.48 & (6.88) & 5.81 & $* *$ \\
\hline Reading & $42.38 \quad(4.80)$ & (4.98) & 1.92 & $(453)$ & -4.31 & $* * *$ \\
\hline Total & $426.73(35.05)$ & 445.28 (32.39) & 1855 & $(4.5)$ & $-历 1$ & $* * *$ \\
\hline
\end{tabular}

To examine the changes in the learners' beliefs about language learning we will consider the differences in the students' responses to the Learner Belief Questionnaire prior to and after their stay in the U.S. Table 5 compares mean responses to the questionnaire items relating to the three main factors measured by the questionnaire. Here it can be seen that the period abroad appeared to have had the strongest effect on SelfEfficacy and Confidence. Prior to going overseas, this factor ranked last out of the three factors, whereas on return it ranked second. The mean difference score for the 166 learners on this factor was .48, the greatest of the three factors. The period abroad also had an effect on beliefs relating to Experiential and Analytic Learning, resulting in mean differences of .25 and .17 respectively. All these differences were statistically significant at the $p<.001$ level. 
Table 5: Mean Scores for the Three Belief Factors Before and After Studying Abroad

Time 1

Time 2

\begin{tabular}{|c|c|c|c|c|c|c|c|}
\hline Factors & Rank & $M(S D)$ & Rank & $M(S D)$ & $M$ Diff. & $t$ & $p$ \\
\hline 1. Analytic Learning & 2 & $2.85(0.52)$ & 3 & $3.02(055)$ & 0.17 & -4.09 & Noper \\
\hline 2. Experiential Learning & 1 & $4.13(0.43)$ & 1 & $4.38(0.47)$ & 0.25 & -6.19 & wow \\
\hline $\begin{array}{l}\text { 3. Self-Efficacy and } \\
\text { Confidence }\end{array}$ & 3 & $2.57(0.72)$ & 2 & $3.05(0.79)$ & 0.48 & -8.38 & Nowe \\
\hline
\end{tabular}

Table 6 below shows the results for the five beliefs that produced the greatest and the least change. Three of the beliefs (\#s 26, 16, and 6) that showed the greatest changes concerned Self-Efficacy and Confidence. All these beliefs strengthened as a result of the study-abroad program.

Table 6: Belief Statements Showing the Greatest and Least Change

\begin{tabular}{|c|c|c|c|c|c|c|c|}
\hline \multirow[t]{2}{*}{ Questionnaire Items } & \multicolumn{2}{|r|}{ Time 1} & \multicolumn{2}{|r|}{ Time 2} & \multirow[b]{2}{*}{ M Diff. } & \multirow[b]{2}{*}{$\mathrm{t}$} & \multirow[b]{2}{*}{$\mathrm{p}$} \\
\hline & Rank & $\mathrm{x} \quad \mathrm{M}(\mathrm{SD})$ & Rank & $\mathrm{M}(\mathrm{SD})$ & & & \\
\hline (Most changed) & & & & & & & \\
\hline $\begin{array}{l}\text { 17. Teacher explains in } \\
\text { my L1. }\end{array}$ & 15 & $3.57(0.94)$ & 21 & $2.90(1.07)$ & -0.67 & 7.55 & $* * *$ \\
\hline $\begin{array}{l}\text { 26. Possible not to get } \\
\text { nervous. }\end{array}$ & 25 & $2.37(0.99)$ & 20 & $2.93(1.12)$ & 0.56 & -7.26 & $* * *$ \\
\hline $\begin{array}{l}\text { 16. Satisfied with my } \\
\text { progress. }\end{array}$ & 27 & $2.06(0.84)$ & 23 & $2.58(1.04)$ & 0.52 & -6.51 & $* * * *$ \\
\hline $\begin{array}{l}\text { 2. Difficult to correct } \\
\text { mistakes later. }\end{array}$ & 13 & $3.61(0.95)$ & 17 & $3.13(1.04)$ & -0.48 & 5.68 & wat \\
\hline $\begin{array}{l}\text { 6. Doesn't matter if I } \\
\text { make mistakes. }\end{array}$ & 18 & $3.25(1.11)$ & 11 & $3.64(1.08)$ & 0.40 & -4.36 & $* * *$ \\
\hline (Least changed) & & & & & & & \\
\hline 12. Studying overseas. & 2 & $4.43(0.78)$ & 5 & $4.51(0.80)$ & 0.07 & -1.10 & \\
\hline $\begin{array}{l}\text { 18. Teacher maintains } \\
\text { good discipline. }\end{array}$ & 19 & $3.20(1.04)$ & 18 & $3.12(1.10)$ & -0.08 & 0.90 & \\
\hline 5. Learning grammar. & 17 & $3.25(1.01)$ & 15 & $3.33(1.07)$ & 0.08 & -1.02 & \\
\hline $\begin{array}{l}\text { 15. Studying English just } \\
\text { for pleasure. }\end{array}$ & 3 & $4.43(0.75)$ & 4 & $4.51(0.73)$ & 0.08 & -1.21 & \\
\hline 25. Learning vocabulary. & 6 & $4.13(0.70)$ & 7 & $4.20(0.77)$ & 0.08 & -1.30 & \\
\hline
\end{tabular}


Thus, the students felt more confident in speaking English, were more satisfied with their progress and were less concerned about making mistakes when they returned to Japan. The other two beliefs (\#s 17 and 2) that showed substantial change, related to Analytical Learning. In both cases this involved a weakening of beliefs. All five of the beliefs that changed the least were related to Analytic or Experiential Learning.

To examine the relationship between beliefs and language proficiency, Pearson correlation coefficients were computed between the learners' mean scores for the three major factors measured by the Learner Belief Questionnaire and their TOEFL scores. The correlations prior to and subsequent to the study-abroad period are shown in Tables 7 and 8, respectively. At Time 1, beliefs about Experiential Learning were related only weakly (and non-significantly) to TOEFL scores. In contrast, slightly stronger (yet statistically significant) relationships were found between beliefs about Analytic Learning and TOEFL scores (Listening and Total). However, these were negative; thus, learners who attached greater importance to Analytic Learning did worse on the TOEFL. Similar results were obtained for Time 2 when the students were about to return from the study-abroad, although on this occasion beliefs about Analytic Learning were negatively related to Reading and Total scores. The analyses failed to reveal any relationship between beliefs concerning either Experiential Learning and proficiency or between Self-Efficacy and Confidence and proficiency at either Time 1 (prior to study-abroad) or Time 2 (subsequent to study-abroad). None of the correlations approached statistical significance.

\section{Table 7: Relationship Between Beliefs and Proficiency Before Studying Abroad}

\begin{tabular}{lcccc}
\hline & Listening & Grammar & Reading & Total \\
\hline 1. Analytic Learning & $-0.17^{*}$ & -0.15 & -0.13 & $-0.20^{* * *}$ \\
2. Experiential Learning & -0.03 & -0.01 & -0.04 & -0.03 \\
3. Self-Efficacy and Confidence & 0.11 & 0.08 & 0.02 & 0.09 \\
\hline
\end{tabular}

$* * p<.01, * p<.05$ 
Table 8: Relationship Between Beliefs and Proficiency after Studying Abroad

\begin{tabular}{lcccc}
\hline & Listening & Grammar & Reading & Total \\
\hline 1. Analytic Learning & -0.14 & -0.07 & $-0.18^{*}$ & $-0.18^{*}$ \\
2. Experiential Learning & 0.01 & 0.01 & 0.08 & 0.05 \\
3. Self-Efficacy and Confidence & 0.09 & 0.09 & 0.13 & 0.14 \\
\hline
\end{tabular}
$* p<.05$

Finally, the relationship between changes in learners' beliefs and gains or losses in proficiency was examined. To measure the extent to which learners' beliefs changed, their belief scores for Time 1 were subtracted from their belief scores for Time 2. Mean belief scores for the three general factors were then computed for each learner. Gains and losses in proficiency were similarly calculated by subtracting Time 1 TOEFL scores from the Time 2 scores. The results of the subsequent correlational analyses are shown in Table 9. The correlations were very weak and statistically non-significant.

\section{Table 9: Relationship Between Changes in Beliefs and Gains/Losses in Proficiency}

\begin{tabular}{lcccc}
\hline & Listening & Grammar & Reading & Total \\
\hline 1. Analytic Learning & -0.09 & 0.00 & -0.03 & -0.06 \\
2. Experiential Learning & -0.06 & -0.06 & 0.01 & -0.05 \\
3. Self-Efficacy and Confidence & -0.04 & -0.06 & 0.01 & -0.04 \\
\hline
\end{tabular}

\section{Discussion}

The discussion will begin with a consideration of the validity and reliability of the belief questionnaire. As previously explained, the development of the belief questionnaire involved testing it on two separate samples of learners prior to its use in this study. Factor analyses of the learners' responses to the two administrations of the questionnaire in this study corresponded closely to those obtained from two earlier samples of L2 learners-they revealed three principal factors: Analytic Learning, Experiential Learning, and Self-Efficacy and Confidence. These factors also corresponded closely to the conceptual categories that had informed the choice of belief statements for the questionnaire. Thus, there are grounds for claiming that the questionnaire is a valid measure of Japanese learners' beliefs about language learning. However, 
it should be noted that the three factors only accounted for $22 \%$ and $30 \%$ of the accumulated variance in learners' responses in the two administrations of the instrument. This suggests that, although the three factors are distinct dimensions in these learners' belief systems, they by no means account fully for differences in these belief systems. The measures of the reliability obtained for the items relating to the separate factors are low, only one reaching an alpha level of .80 (Analytic Learning at Time 2). However, these measures should be seen in the context of measures of reliability obtained for learner belief questionnaires in other studies. For example, Yang (1992) reported alphas ranging from .52 to .71 for the four factors that emerged from a factor analysis of the 35-item BALLI administered to 505 Taiwanese university students. Sakui and Gaies (1999) reported alphas ranging from .46 to .75 for the four factors measured by their questionnaire administered to a sample of Japanese university students similar to the sample investigated in this study. Thus, the alphas obtained in this study compare favourably with those reported in other similar studies. The question arises as to why the alpha levels for belief questionnaires appear to be consistently low. A likely explanation is that learners' belief systems are not homogeneous. As has been frequently noted, learners can hold beliefs that appear to be contradictory.

The first research question addressed the changes in the learners' English language proficiency. The mean total TOEFL score advanced from 427 to 445 . Although this was statistically significant, the gain seems moderate given the length and nature of the learning experience ${ }^{2}$. Swinton (1983), for example, reported a 52.3 (12\%) total point gain for students in the same pre-test TOEFL range as the students in this study ${ }^{3}$. The students Swinton investigated were enrolled for a semester (i.e., approximately 15 weeks) in an intensive English program at San Francisco State University. However, Swinton does not give detailed information about the participants' backgrounds, so it is not clear to what extent they can be compared with the Japanese sample of this study.

Previous research (e.g., Freed, 1995, 1998) has shown that studying abroad is related to low gains in proficiency in advanced learners. However, the learners in this study can hardly be considered advanced. A possible explanation for the modest gains manifested by the Japanese sample is that the learners constituted a linguistically and culturally homogeneous group who had had little need to use English outside the classroom. If these students had been dispersed into mixed groups 
of learners (as happens, for example, in a typical intensive English language program at American universities) and/or if they had been housed in home-stays with English-speaking hosts, greater gains might have occurred.

This conclusion is supported by an analysis of the gains on the different sections of the TOEFL. Whereas previous studies have found that grammatical proficiency is least influenced by study-abroad, this study found that gains in the Grammar section of the TOEFL were greater than gains in the Listening or Reading sections. The greater gain in grammatical proficiency may reflect the fact that, for these students, it was the classroom instruction rather than the opportunities to communicate in English that had the greater impact on their proficiency.

The second research question addressed the changes that occurred in learners' beliefs about language learning. The results show that the learners' beliefs concerning all three general factors strengthened and that this change was statistically significant in the case of all three factors. The greatest change occurred in beliefs concerning Self-Efficacy and Confidence. The experience of living in an English-speaking country and of being taught intensively through the medium of English by native speakers appears to have had a major impact on these learners' beliefs about their ability to speak English without feeling unduly nervous, about not worrying about mistakes while speaking English, and about their general progress. This enhanced confidence can be considered, perhaps, the major achievement of the study-abroad program for these students, especially if it subsequently pays off in promoting learning on their return to Japan. Changes in beliefs reflected in the Analytic and Experiential Learning factor were less pronounced, with beliefs relating to the latter showing the greater changes, as might be expected given the opportunities that the learners had to experience the communicative use of English while in the United States. The fact that beliefs relating to Analytic Learning also strengthened significantly may reflect the students' growing recognition that accuracy in the use of English is important. This study, then, indicates that learner beliefs are dynamic, influenced by their environment and the learning experiences it affords them. However, without a control group, it is not possible to attribute the strengthening of beliefs evident in the sample studied to their study-abroad program.

The third research question addressed the relationship between the learners' beliefs and their proficiency. No relationship between 
beliefs relating to Self-Efficacy and Confidence and TOEFL scores was found either before or after the period abroad. There are two possible explanations for this. The first is that Self-Efficacy and Confidence may be more strongly related to measures of oral language use than to the kind of proficiency measured by the TOEFL. Second, the relationship between confidence and proficiency may be a delayed rather than a concurrent one. This is a point that will be considered further below.

Learners' beliefs about Analytic Learning were negatively related to the TOEFL measures. Given the nature of the TOEFL test (i.e., its emphasis on discrete point testing of grammar and vocabulary) we anticipated that learners committed to Analytic Learning would perform better on the test. In fact, they did worse. One possible explanation is that, despite common perceptions (especially in Japan), an analytic approach (e.g., memorising grammar rules and vocabulary) is not an effective means of preparing for the TOEFL and, in fact, may have a negative impact on test performance. It should be noted, however, that out of a total of 216 correlations between belief scores and TOEFL scores at Times 1 and 2 there were only five statistically significant positive coefficients ${ }^{4}$ ! This suggests that the construct of "language learning" that informed the learners' responses to the belief questionnaire was very different from the construct of "language learning" that underlies the TOEFL.

The final research question concerned the relationship between changes in learners' belief systems and gains/losses in proficiency. No relationship between changes in beliefs and proficiency was found. For example, even though significant gains were evident in the students' beliefs about their Self-Efficacy and Confidence, these were not related to immediate gains in proficiency. A possible explanation for this finding is that it takes time for changes in learners' belief systems to have any effect on their proficiency and that the period between the administrations of the questionnaire and the TOEFL test was not sufficiently long enough for any effect to become evident. Changes in beliefs need to be translated into changes in actual learning behaviours before any impact on proficiency will become evident and such a transition probably does not occur immediately.

\section{Conclusion}

This article has reported an exploratory study of the relationship between learner beliefs and L2 proficiency in the context of a 15-week study-abroad program for 166 Japanese learners of English. The results can be summarised as follows: 
1. Statistically significant gains in proficiency, as measured by the TOEFL, occurred during the study-abroad program.

2. Statistically significant changes in the learners' beliefs occurred during the study-abroad program. The strongest effect was evident in beliefs relating to Self Efficacy and Confidence.

3. Statistically significant relationships between beliefs and proficiency were found both prior to and subsequent to the study-abroad program. Strong beliefs about the importance of analytic learning were found to be inversely related to TOEFL scores.

4. No statistically significant relationships were found between changes in beliefs and gains or losses in proficiency.

One conclusion to be drawn from this study is that the extent to which learners gain from a study-abroad experience will depend to a considerable extent on the nature of the program. The program that we investigated can be characterised as a "Japanese College Overseas." Students studied in homogeneous classes and lived together in dormitories. It is true that native speaking teachers taught them, but that was also the case in their Japan-based university. It is not clear therefore, whether the study-abroad context these students experienced was substantially different from the learning context in Japan. This may account for why the gains in proficiency appeared quite moderate. However, without a comparison group of learners who remained in Japan it is not possible to comment conclusively on the extent of the gains manifested by the participants in this study-abroad program. A limitation of this study is that there was no such comparison group.

A second conclusion is that Japanese learner beliefs about language learning can be classified into three types, relating to Analytic Learning, Experiential Learning and Self-Efficacy and Confidence. However, these factors accounted for less than a third of the variance in the learners' responses to the belief questionnaire. There is an obvious need to investigate what other factors figure in learners' belief systems about language learning.

The strengthening of the students' beliefs about language learning, especially in the area of Self-Efficacy and Confidence, might be seen as one of the major gains of this study-abroad program. However, again, before these gains can be definitely attributed to the study-abroad 
experience it will be necessary to demonstrate that similar gains do no arise in comparable students who remain in Japan. This study suggests that strong beliefs about the value of analytic learning are negatively related to performance on the TOEFL. If this finding is replicated in other studies, it will suggest the need for students to re-evaluate their belief systems, giving less emphasis to an analytic approach when preparing to take the TOEFL.

The relatively weak relationship between stated beliefs and measures of proficiency may reflect the indirect nature of this relationship, which is mediated by the actual learning behaviours (e.g., learning strategies) that learners engage in. Learners may change their behavioural beliefs but not their behaviours. As a result, the changes do not affect their learning. Investigating the relationship between beliefs, behaviours and learning outcomes may best be undertaken by in-depth case studies of individual learners using case study methods, rather than the quantitative methods employed in the study reported here.

\section{Acknowledgements}

The authors would like to thank Shawn Loewen for his statistical assistance. They also benefited greatly from the reports of the three anonymous reviewers of the article.

Koichi Tanaka is currently a lecturer in Japanese at the Auckland Institute of Studies, New Zealand. His doctoral studies in the Department of Applied Language Studies at the University of Auckland entail a study of Japanese students' beliefs about L2 learning.

Rod Ellis is Professor and Head of the Department of Applied Language Studies and Linguistics at the University of Auckland. He has published widely in SLA and language teaching, his most recent book being TaskBased Language Learning and Teaching (Oxford University Press).

\section{Notes}

1. The Cronbach's alpha for Experiential Learning at Time 1 is very low (only .29). This is mainly due to the effect of one statement (\#14). If this statement is removed, the alpha increases to .64, which is a similar level to that reported for most of the other factors.

2. The TOEFL gains for the 2000 cohort of students on the study-abroad program were in the same range as those for other years (e.g., in 1996 the gain was 4.8\%, in $19974.4 \%$ and in 1998 6.9\%). Only in 1999 was a 
notably higher average gain recorded (13.3\%).

3. There were correspondingly greater gains in the different sections of the TOEFL by Swinton's participants; Listening (9.9; 22\%), Structure and Written Expression ( 4.2; 9.5\%), and Reading Comprehension and Vocabulary $(4.8 ; 10.7 \%)$. It is interesting to note the greatest gain in Swinton's sample was in Listening, which showed the smallest gain in the sample in this study.

4. The five significant correlations between belief statements and TOEFL scores were (1) "I am satisfied with my progress" and TOEFL Listening at Time $1(r=.23)$, (2) "I am satisfied with my progress" and TOEFL Total at Time $1(r=.22)$, (3) "I can learn well if I try to think in English" and TOEFL Total at Time 1 ( $r=16$ ), (4) "I am and satisfied with my progress" and TOEFL Reading at Time $2(r=.16)$ and (5) "It's okay to guess if I do not know a word in English" and TOEFL Reading at Time $2(r=.18)$. These belief statements relate to Self-Efficacy and Confidence or to Experiential Learning. There were no significant correlations involving Analytic Learning.

\section{References}

Carroll, J. (1967). Foreign language proficiency levels attained by language majors near graduation form college. Foreign Language Annals, 1, 131-151.

Coleman, J. (1997). Residence abroad within language study. Language Teaching, 30, 1-20.

Corsini, R. (Ed.). (1994). Encyclopaedia of psychology (2nd. ed.). New York: John Wiley and Sons.

Ellis, R. (1994). The study of second language acquisition. Oxford: Oxford University Press.

Fishbein, M., \& Ajzen, I. (1975). Belief, attitude, intention and behavior: An introduction to theory and research. Reading: Addison-Wesley.

Freed, B. (1990). Language learning in a study abroad context: The effects of interactive and non-interactive out-of-class contact on grammatical achievement and oral proficiency. In J. Atlatis (Ed.), Georgetown University round table on languages and linguistics 1990 (pp.459-477). Washington D.C.: Georgetown University Press.

Freed, B. (1993). Assessing the linguistic impact of study-abroad: What we currently know - what we need to learn. Journal of Asian Pacific Communication, 4 , 151-161.

Freed, B. (1995). Language learning and study-abroad. In B. Freed (Ed.), Second language acquisition in a study-abroad context (pp. 3-33). Amsterdam: John Benjamins.

Freed, B. (1998). An overview of issues and research in language learning in a study-abroad setting. Frontiers: The Interdisciplinary Journal of Studyabroad, 4, 21-60. 
Gardner, R., \& MacIntyre, P. (1992). A student's contributions to second language learning. Part I: Cognitive variables. Language Teaching, 25, 211-220.

Gardner, R., \& MacIntyre, P. (1993). A student's contributions to second language learning. Part II: Affective variables. Language Teaching, 26, 1-11.

Horwitz, E. (1985). Using students beliefs about language learning and teaching in the foreign language methods course. Foreign Language Annals, 18, 333340.

Horwitz, E. (1988). The beliefs about language learning of beginning university foreign language students. Modern Language Journal, 72, 283-294.

Horwitz, E. (1999). Cultural and situational influences on foreign language learners' beliefs about language learning: A review of BALLI studies. System, 27, 557-576.

Kern, R. (1995). Students' and teachers' beliefs about language learning. Foreign Language Annals, 28, 71-91.

Matsuura, H., Chiba, R., \& Hilderbrandt, P. (2001). Beliefs about learning and teaching communicative English in Japan. JALT Journal, 23, 69-89.

Mori, Y. (1999). Epistemological beliefs and language learning beliefs: What do language learners believe about their learning? Language Learning, 49, 377415.

Park, G. (1995). Language learning strategies and beliefs about language learning of university students learning English in Korea. Unpublished doctoral dissertation, University of Texas at Austin.

Rifkin, B. (2000). Revising beliefs about foreign language learning. Foreign Language Annals, 33, 394-420.

Sakui, K., \& Gaies, S. (1999). Investigating Japanese learners' beliefs about language learning. System, 27, 473-492.

Swinton, S. (1983). A manual for assessing language growth in instructional settings: TOEFL research report 14. Princeton: Educational Testing Service.

Tanaka, K. (1999). The development of an instrument to investigate learners' beliefs about language learning. Unpublished seminar paper, Department of Applied Language Studies and Linguistics, University of Auckland.

Tanaka, K. (2000). The effect of learning environment on learner beliefs about language learning: A cross-cultural study on learners of English in New Zealand and Japan. Paper presented at the 7th National Conference on Community Language and English for Speakers of Other Languages, Auckland, New Zealand.

Wenden, A. (1986). What do second-language learner know about their language learning?: A second look at retrospective accounts. Applied Linguistics, 7 , 186-205.

Yang, N. (1992). Second language learners' beliefs about language learning and their use of learning strategies: A study of college students of English in Taiwan. Unpublished doctoral dissertation. University of Texas at Austin. 


\section{Appendix}

Belief Statements:

1. I can learn well by speaking with others in English

2. If I am permitted to make mistakes in English, it will be difficult for me to speak correctly later on.

3. I can learn well if I try to study English outside class on my own.

4. I can learn English well by writing down everything in my notebook.

5. In order to speak English well, it is important for me to learn grammar.

6. It doesn't matter if I make mistakes when speaking with others in English.

7. In order to learn well, it is important for me to review what I have been taught in the English class.

8. I should be able to understand everything I read in English.

9. In order to learn well, it is important for me to try to think about my progress in English.

10. I can learn well by listing to radio or watching TV in English.

11. Memorisation is a good way for me to learn English.

12. I can learn English well by living in an English-speaking country (e.g., U.S.A.).

13. I can learn English well by following a textbook.

14. I should not be forced to speak in the English class.

15. I can learn English well if I am studying just for pleasure.

16. I am satisfied with my progress in English so far.

17. I would like my English teacher to explain important things in my first language so I can understand everything.

18. I can learn English well in a class where the teacher maintains good discipline.

19. I can learn well by using English outside class.

20. I should be able to understand everything the teacher says in the English class.

21. It's okay to guess if I do not know a word in English.

22. I can learn well by reading English magazines or newspapers.

23. It is possible for me to learn to speak English very well.

24. I can learn well if I try to think in English.

25. In order to speak English well, it is important for me to learn vocabulary.

26. It is possible for me not to get nervous when speaking English.

27. I would like my English teacher to correct all my mistakes. 